\title{
An empirical analysis of price differences for male and female artists in the global art market
}

\author{
Fabian Y. R. P. Bocart ${ }^{1} \cdot$ Marina Gertsberg $^{2}$ (D) Rachel A. J. Pownall ${ }^{3}$
}

Received: 9 February 2020 / Accepted: 28 October 2020 / Published online: 13 February 2021

(c) The Author(s) 2021

\begin{abstract}
We study prices paid at auction for artworks created by male and female artists, based on birth-identified sex, and how these prices have evolved over time. Artworks produced by female artists comprise less than $4 \%$ of art auction sales; after controlling for artwork characteristics, we find that artworks by female artists are $4.4 \%$ more expensive than artworks by male artists. In the top echelon of the art market—for sales above \$1 millionartworks by male artists sell for $18.4 \%$ more than by female artists. The top 40 artists represent $40 \%$ of total market share; no female artist makes the top 40 ranking of artists in terms of total sales value at auction in the period under study, 2000-2017. However, for contemporary artists, our empirical results show that works by male artists sell for $8.3 \%$ more than their female counterparts. Overall, this study highlights significant price differences across birth-identified sex in the secondary market for fine art.
\end{abstract}

Keywords Art market $\cdot$ Auctions $\cdot$ Gender economics $\cdot$ Labour economics

\begin{abstract}
We would like to thank Pierre-André Chiappori, Dakshina De Silva, Jonathan Feinstein, Raffi Garcia, William Goetzmann, Claudia Goldin, Kathryn Graddy, Michaela Pagel, Leonard Wolk, the seminar and conference participants at Bocconi University, Maastricht University, Sydney University, Monash University, ESSFT Gerzensee, the International Industrial Organization Conference, the Conference on Auctions, Competition, Regulation and Public Policy, the Annual Conference of the Society for Institutional \& Organizational Economics, the Annual Meeting of the Financial Management Association, and the Yale Symposium on Art and Gender for valuable comments.
\end{abstract}

Rachel A. J. Pownall

r.pownall@maastrichtuniversity.nl

Fabian Y. R. P. Bocart

FBocart@artnet.com

Marina Gertsberg

marina.gertsberg@monash.edu

1 Artnet Worldwide Corporation, 233 Broadway, New York 10279-2600, USA

2 Monash Business School, Monash University, 900 Dandenong Road, Caulfield East VIC 3145, Australia

3 Maastricht University, P.O. Box 616, 6200 MD Maastricht, The Netherlands 
JEL Codes $\mathrm{J} 24 \cdot \mathrm{J} 31 \cdot \mathrm{J} 71 \cdot \mathrm{Z} 11$

\section{Introduction}

Artworks by female artists represent only 3\% to 5\% of major permanent collections in the USA and Europe (National Museum of Women in the Arts 2017), and this fraction is reflected in a similar percentage of artworks by female artists sold at auction globally; according to auction sales data from artnet, this is less than $4 \%$. Historically there were far fewer female artists; however, in more recent generations roughly $50 \%$ of all Master of Fine Arts (MFA) holders are female in the USA. It has been noted that their share drops to $30 \%$ in commercial US galleries (National Museum of Women in the Arts 2017) and to 25\% at art fairs (McAndrew 2018).

In this large-scale empirical study, we analyze how the fraction of male and female artists selling at auction has evolved over time and estimate the size of any relative price differences between these two groups, after controlling for conventional artwork characteristics. Our curiosity in the pricing of artworks across different birth identities is to further our understanding of whether there are any differences in artistic characteristics of female produced artworks. As the share of female produced artworks has significantly increased over time, this will be reflected in the art market more broadly.

We use auction data representing nearly the whole population of auction transactions in the time period between 2000 and 2017. We also employ a smaller primary (gallery) market data set to investigate how the share differs between the primary and the secondary (auction) market for male and female artists. We find that femaleproduced artworks have a lower price than male-produced artworks when we do not control for artwork characteristics. However, after controlling for conventional artwork characteristics, female-produced artworks trade at a higher average price. This is suggestive that the difference in prices is reflective of differences in artistic characteristics of female-produced artworks.

\section{Data}

\subsection{Sample}

Our dataset comprises almost the full population of global art auction transactions between 2000 and 2017 from artnet AG, covering over 1800 auction houses., ${ }^{1,2}$ Auction sales characteristics include the auction house name, the sale date, the lot number, the auction house pre-sale estimate and the hammer price in US Dollars

\footnotetext{
${ }^{1}$ We exclude decorative art, antiques, ceramics, furniture, jewellery, and watches, since our focus is the fine art sector. The fine art category includes photography, prints and multiples, works on paper, paintings, installations, design objects and sculptures.

${ }^{2}$ This includes the largest auction houses such as Sotheby's, Christies, Poly International, Phillips, China Guardian and Dorotheum, as well as predominately online auction houses such as Heritage and Heffel. Transactions are required to have a minimum estimate of $\$ 500$ to be included in the database.
} 
before transaction costs. We deflate all prices using the US consumer price index using 2017 as our base year. ${ }^{3}$ With respect to the artists' attributes, the database records name, date of birth, living status and nationality. At an artwork level, we have information on the title of the work, its size and object type. We categorize auction transactions into movements based on the birth year of the artist following the classification in the Tefaf (Pownall 2017) and the Art Basel and UBS Global Art Market Reports (McAndrew 2018), into Old Masters and Impressionists (1250-1874), Modern (1875--1910), Post War (after 1911 and deceased) and Contemporary (all living artists). ${ }^{4}$

Our variable of interest is the artists' birth sex. Since artnet's price database does not indicate the birth sex of the artists, we identified female artists by matching them to a number of name lists, and use name as a proxy for birth-identified sex. We use a list provided by the Museum of Modern Art that lists name and birth sex of 70,000 major artists. We use a probabilistic approach to match the remaining artist names to their likely birth sex based on name lists. ${ }^{5}$ In order to ensure accuracy and increase the homogeneity of the artists in our sample in terms of opportunities such as access to education, we focus on Western artists who are based in Europe and North America. ${ }^{6,7}$ We also drop observations where information on artwork size is missing. ${ }^{8}$ Lastly, we exclude bought-in lots from our main analysis. ${ }^{9}$ Our final sample consists of 2,677,190 auction transactions for 116,550 artists (Tables 1 and 2 ).

\subsection{Descriptive statistics}

Table 3 shows the summary statistics for auction prices for male and female artists, by artistic movement, object type, region and living status. The final column presents the difference between mean male and female prices. Overall, $96.1 \%$ $(2,572,346)$ of all artworks sold at auction between 2000--2017 are attributed to

\footnotetext{
3 The US consumer price index provided by the OECD: https://data.oecd.org/price/inflation-cpi.htm.

4 The artworks where the artist's birth year was not available are subsumed under "other". We do not consider artists born before 1250 . We acknowledge that there are alternative ways as to how one may classify artists into movements (e.g., by year of artwork creation).

5 We started from a list provided by MOMA (https://github.com/MuseumofModernArt/collection) which covers about 70,000 artists. For these 70,000 artists, we know their sex unambiguously. For the remaining names, we use a list for US baby names provided by the SSA (https://www.ssa.gov/oact/babyn ames/limits.html). Over $50 \%$ are identified with $90 \%$ precision or higher. We next use a list compiled by the German computer magazine Heise which covers European names (ftp://ftp.heise.de/pub/ct/listings/0717-182.zip.).

6 Asian artists, whose names are difficult to decode, account for less than $0.2 \%$ of artists in our sample and for $0.2 \%$ of sales. As a result, even in the unfortunate case of mis-classification, this should not affect our results. In cases where the name was unisex, we manually researched the identity of the artist. Instances where the artist consisted of more than one person were dropped from the sample.

7 Whenever there were two nationalities attributed to an artist, the name was included in the sample if either nationality was European or North American.

8 There are 58,166 transactions where information on size is missing.

9 In auctions, a buy-in takes place when an artwork is not sold as it fails to meet the seller's reserve price. The buy-in rate in our sample is $37.73 \%$ which is in line with the commonly observed buy-in rates in auction sales.
} 


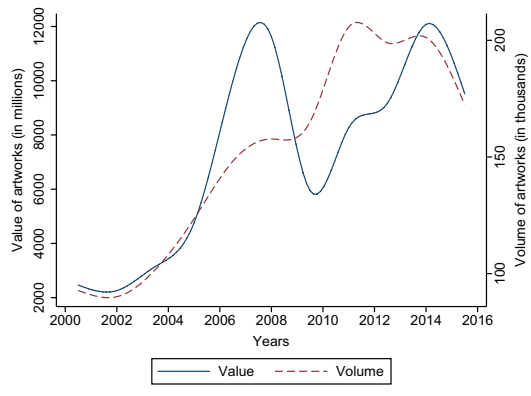

(a) Number and value of artworks by men by years

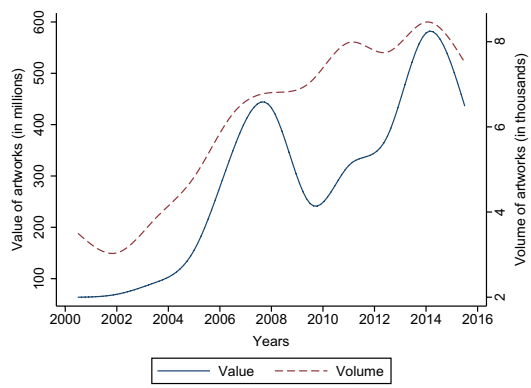

(c) Number and value of artworks by women by years

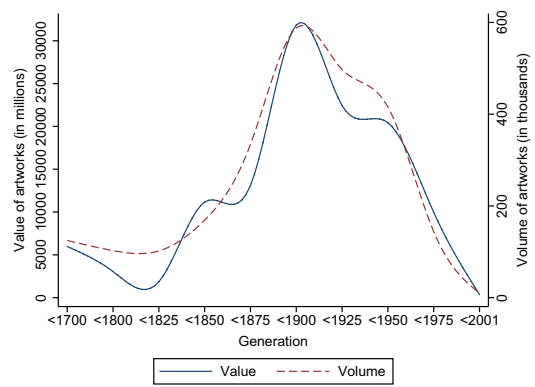

(b) Number and value of artworks by men by generation

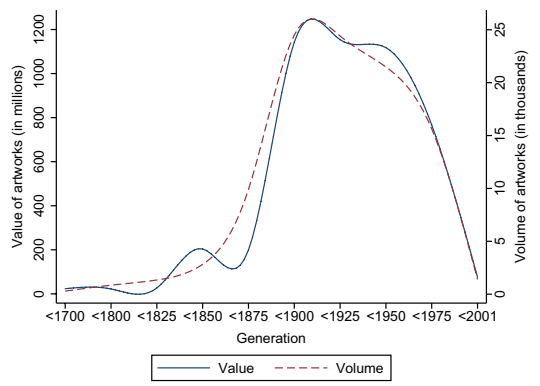

(d) Number and value of artworks by women by generation

Fig. 1 Evolution of sales by male and female artists. The year 2017 is omitted in Figures a and c as we only use the first four months of this year. Overall, there were 35,860 artworks by male and 1787 artworks by female artists in this year. The value of these artworks is $\$ 1,521,769,000$ and $\$ 53,611,000$, respectively. Due to missing data on the year of birth, not all artists could not be allocated to a generation. Figures $\mathbf{b}$ and $\mathbf{d}$ omit these artists. Overall, there are 89,888 artworks by male and 2199 artworks by female artists in this omitted category. The value of these artworks is $\$ 761,310,000$ and $\$ 7,780,000$, respectively.

male artists. Figure 1 shows that sales volumes have increased overall, with a larger relative increase for women. Over the sample period (Fig. 1a,c), sales of artworks by females increased by a multiple of 6.0, while sales of male artworks increased by a multiple of 2.8. Nevertheless, female artists remain a small fraction of the overall market in terms of both volume (4.2\%) and value (5.0\%). Over generations, sales numbers increased rapidly for artists born after 1875 (Fig. 1b,d). Again, this increase is more pronounced for female artists.

With respect to the number of artists, men dominate the auction market representing $95.2 \%$ of the artists sold at auction. While there are 110,938 male artists, there are only 5612 female artists. The proportion of female artists is highest for Contemporary art (9.3\% are from female artists) and smallest for the Old Masters period (2.9\%). Figure 2 shows the evolution of the number of distinct male and female artists over the sample period as well as over the generations (Fig. 2). ${ }^{10}$ Whilst

$\overline{10}$ A generation is defined as 25 years. 


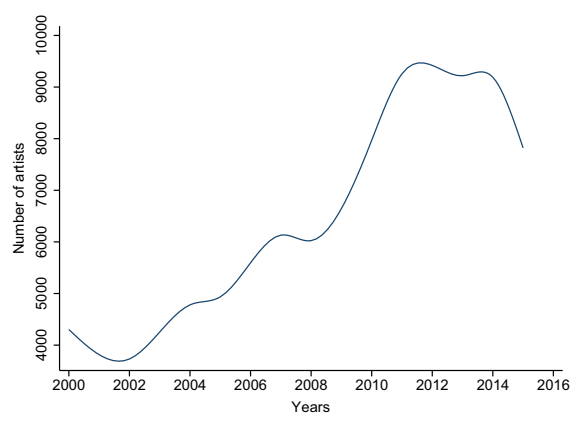

(a) Number of male artists by years

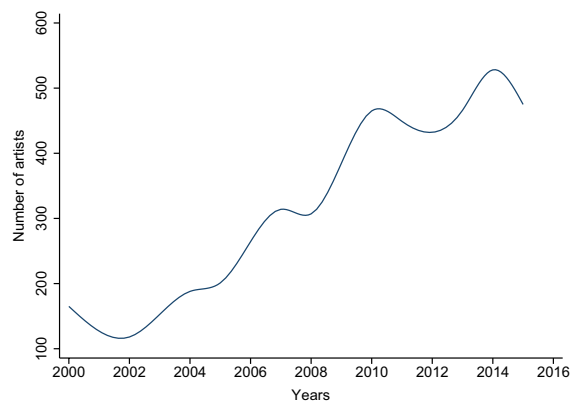

(c) Number of female artists by years

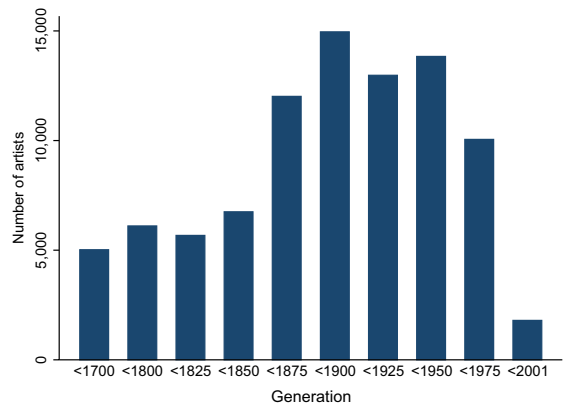

(b) Number of male artists by generation

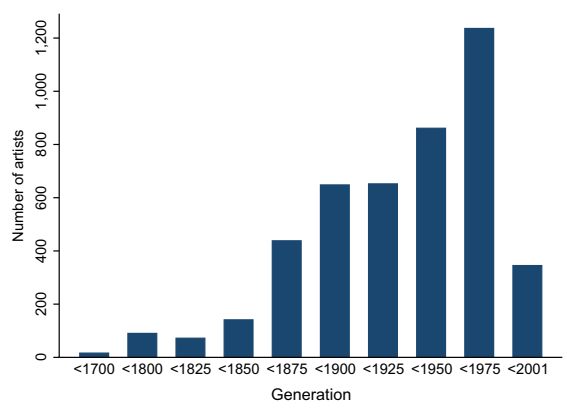

(d) Number of female artists by generation

Fig. 2 Evolution of number of male and female artists. The year 2017 is omitted in Figures a and $\mathbf{c}$ as we only use the first four months of this year. Overall, there were 6171 male and 167 female artists in 2017. Due to missing data on the year of birth, not all artists could not be allocated to a generation. Figures $\mathbf{b}$ and $\mathbf{d}$ omit these artists. Overall, 21,748 male and 1113 female artists could not be allocated to a generation

we observe an increasing trend in the number of recorded artists selling at auction between 2000 and 2017 for both male and female artists, the trend is much greater for the number of female artists; this is highlighted in Fig. 3, which graphs the ratio of the number of female artists to the number of male artists over the period under study (Fig. 3).

We find that while the average prices of female artworks are significantly below the average price for male artworks $(\$ 39,065 \text { versus } \$ 45,614)^{11}$, the median price of $\$ 3931$ is higher for women than for men (\$3649). This is also reflected in Fig. 4 which shows how these numbers have evolved over time and over generations of

\footnotetext{
${ }^{11}$ This is equivalent to an average price difference of $16.8 \%$ which is smaller than the unconditional discount of $47.6 \%$ documented by Adams et al. (2017). Consistent with this study, we also find a negative price difference $(-8.3 \%)$ for female artists when we only consider contemporary artists or artworks selling for more than 1 million $(-17.9 \%)$. It is likely that differences in sample compositions of our studies drive differences in results. Adams et al. (2017) use a sample of 1.5 million global auction transactions between 1970 and 2013 (62,442 artists). In their sample, female artists account for $16.9 \%$ of artists and for $6.9 \%$ of transactions; our focus is on Western artists names as a proxy for birth-identified sex.
} 


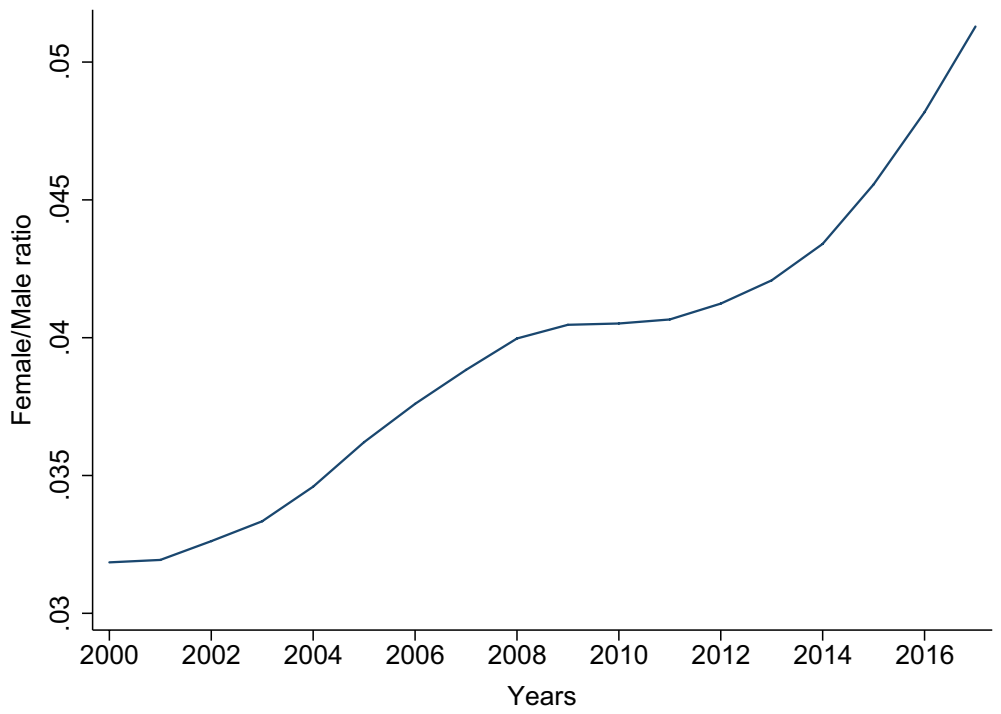

Fig. 3 Evolution female-to-male ratio

artists. In Fig. 4a we observe that mean artwork prices tend to be higher for men, whereas median prices (Fig. 4c) appear to be higher for women after 2002 with a widening gap after 2011. The hedonic price indices based on the respective year dummies in Fig. 5 in the Appendix show that sales prices of female artists have overall outperformed sales prices of male artists (Fig. 5a).

\section{Empirical analysis}

To examine whether artworks by men sell at the same price as women-all other things equal - and thus observe if the patterns in our summary statistics hold after controlling for characteristics, we analyze our data with the following basic model specification:

$$
\log P_{i t}=\alpha+\psi W_{i}+\beta X_{i}+\eta H_{i}+\tau_{t+} \epsilon_{i t}, \quad i=1, \ldots, N ; \quad t=1, \ldots, T ;
$$

In this equation, $\log P_{i t}$ indicates the $\log$ of the real price of an artwork, $i$, which is sold at a given time $t .^{12} N=2,677,190$ artworks in our sample over $T=72$ seasons (Winter, Spring, Summer, and Autumn) between 2000 and 2017 (18 years). $W_{i}$ denotes the birth-identified sex coefficient which is a dummy variable, denoted female, taking a value of 1 whenever the respective artist of a given artwork, $i$, is a woman. This regression specification estimates the differences between the actual sales price for an artwork of a female artist and the value of an artwork by a male

\footnotetext{
12 We also conducted a robustness check where we used the nominal artwork price as our dependent variable. The results remain qualitatively in line with results reported in Table 4.
} 


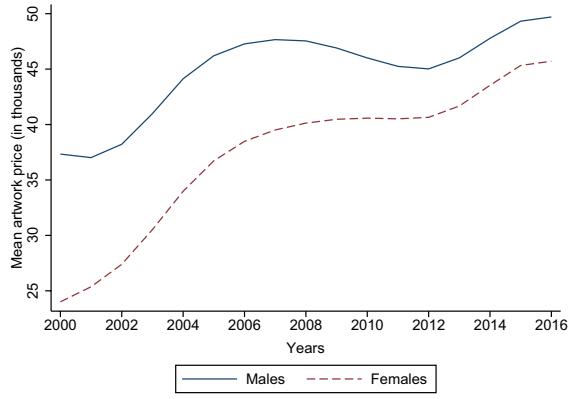

(a) Mean artwork prices by year

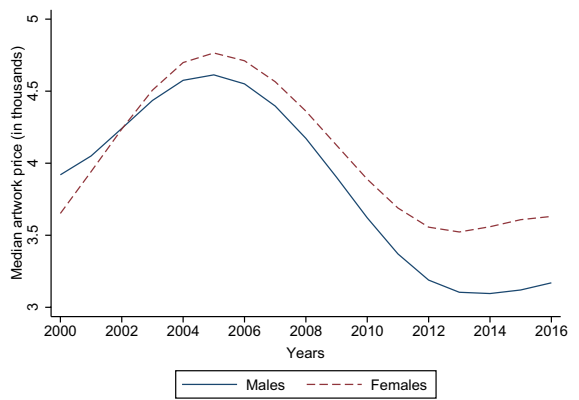

(c) Median artwork prices by year

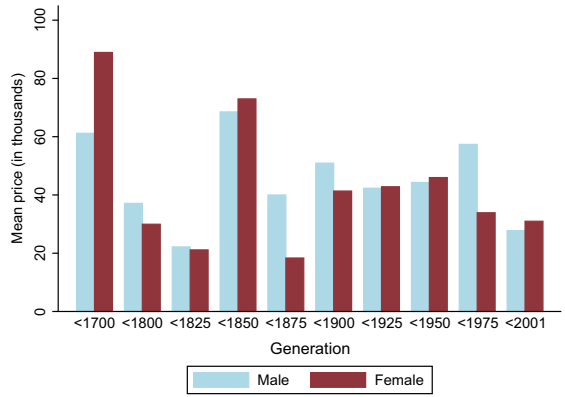

(b) Mean artwork prices by generation

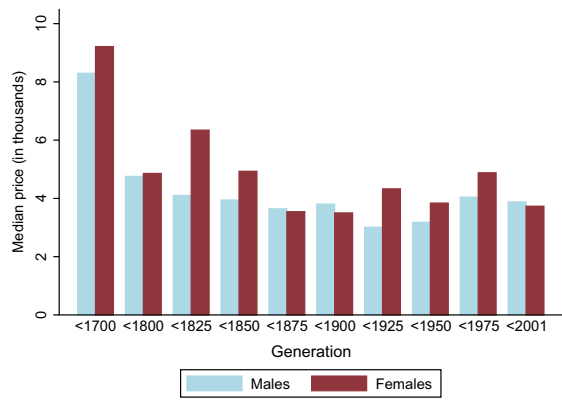

(d) Median artwork prices by generation

Fig. 4 Evolution of mean and median artwork prices for men and women. The year 2017 is omitted in Figures a and $\mathbf{c}$ as we only use the first four months of this year. Overall, the mean (median) value is $\$ 42,436$ ( $\$ 3681)$ for artworks by male and $\$ 30,001$ (\$4306) for artworks by female artists in this year. Due to missing data on the year of birth not all artists could not be allocated to a generation. Figures $\mathbf{b}$ and d omit these artists. Overall, the mean (median) value is $\$ 8968$ (\$1992) for artworks by male and $\$ 3542$ (\$1182) for artworks by female artists in this omitted category

artist with the same characteristics. All artwork characteristics are captured in $X_{i}$, a $1 \times 276$ vector that includes the object type (the base category is paintings), the auction house where it was sold and the size of the artwork. ${ }^{13} H_{i}$ is a $1 \times 5$ vector that denotes the artist characteristics of a given artwork, $i$, including region of the artist's nationality (the base category is North America) ${ }^{14}$ and a dummy for the living status of the artist at the time of the transaction (the base category is 'deceased'). ${ }^{15} \tau$ represents time fixed-effects for the years 2000 until 2017. $\psi, \beta$ and $\eta$ are time-independent parameters. $\alpha$ is a constant term. Lastly, $\epsilon_{i t}$ denotes the error term.

\footnotetext{
13 In total, there are 1522 auction houses in our data set. Due to collinearity concerns, we subsumed auction houses below the 90th quantile in terms of number of transactions under "other". This resulted in 270 different categories.

${ }^{14}$ All countries are allocated into five regions: North America, Eastern Europe, Northern Europe, Southern Europe and Western Europe.

${ }^{15}$ Due to collinearity between the artist names and the female dummy, we exclude artist fixed effects from the regression in our main analysis.
} 
Table 1 Top 50 male artists by value of sales

\begin{tabular}{|c|c|c|c|c|c|}
\hline Rank & Artist & Movement & Total sales value in $\$$ & $\begin{array}{l}\text { Total sales volume } \\
(\text { market share }(\%))\end{array}$ & Average price \\
\hline 1 & Pablo Picasso & Modern & $5,853,551,616(4.99)$ & $37,386(1.45)$ & 156,571 \\
\hline 2 & Andy Warhol & Postwar & $4,931,258,880(4.2)$ & $19,028(0.74)$ & 259,158 \\
\hline 3 & Claude Monet & OldMasters & $2,509,770,496(2.14)$ & $493(0.02)$ & $5,090,813$ \\
\hline 4 & Gerhard Richter & Contemporary & $2,128,574,336(1.81)$ & $3587(0.14)$ & 593,414 \\
\hline 5 & Francis Bacon & Modern & $2,071,435,648(1.77)$ & $1372(0.05)$ & $1,509,793$ \\
\hline 6 & Alberto Giacometti & Modern & $1,661,223,808(1.42)$ & $1991(0.08)$ & 834,367 \\
\hline 7 & Jean-Michel Basquiat & Postwar & $1,604,688,384(1.37)$ & $1308(0.05)$ & $1,226,826$ \\
\hline 8 & Mark Rothko & Modern & $1,589,495,040(1.35)$ & $142(0.01)$ & $11,200,000$ \\
\hline 9 & Henri Matisse & OldMasters & $1,384,500,224(1.18)$ & $5157(0.2)$ & 268,470 \\
\hline 10 & Roy Lichtenstein & Postwar & $1,365,195,904$ (1.16) & $6429(0.25)$ & 212,350 \\
\hline 11 & Amedeo Modigliani & Modern & $1,282,909,952$ (1.09) & $502(0.02)$ & $2,555,598$ \\
\hline 12 & Marc Chagall & Modern & $1,246,740,480(1.06)$ & $14,957(0.58)$ & 83,355 \\
\hline 13 & Joan Miró & Modern & $1,195,891,584(1.02)$ & $14,781(0.57)$ & 80,907 \\
\hline 14 & Willem De Kooning & Modern & $1,144,317,696(0.98)$ & $1272(0.05)$ & 899,621 \\
\hline 15 & Lucio Fontana & Modern & $1,098,615,296(0.94)$ & $2772(0.11)$ & 396,326 \\
\hline 16 & Alexander Calder & Modern & $1,088,666,752(0.93)$ & $5479(0.21)$ & 198,698 \\
\hline 17 & $\begin{array}{l}\text { Pierre-Auguste } \\
\text { Renoir }\end{array}$ & OldMasters & $1,046,396,352(0.89)$ & $3,766(0.15)$ & 277,854 \\
\hline 18 & Zao Wou-Ki & Postwar & $1,015,000,512(0.87)$ & $4045(0.16)$ & 250,927 \\
\hline 19 & Fernand Léger & Modern & $1,005,042,112(0.86)$ & $2978(0.12)$ & 337,489 \\
\hline 20 & Cy Twombly & Postwar & $850,141,376(0.72)$ & $881(0.03)$ & 964,973 \\
\hline 21 & Jeff Koons & Contemporary & $848,892,096(0.72)$ & $1646(0.06)$ & 515,730 \\
\hline 22 & Paul Cézanne & OldMasters & $791,902,080(0.67)$ & $697(0.03)$ & $1,136,158$ \\
\hline 23 & Edgar Degas & OldMasters & $771,783,232(0.66)$ & $1274(0.05)$ & 605,795 \\
\hline 24 & René Magritte & Modern & $734,759,296(0.63)$ & $1519(0.06)$ & 483,713 \\
\hline 25 & Damien Hirst & Contemporary & $705,134,592(0.6)$ & $3940(0.15)$ & 178,968 \\
\hline 26 & Egon Schiele & Modern & $640,337,088(0.55)$ & $810(0.03)$ & 790,540 \\
\hline 27 & Yves Klein & Postwar & $629,027,840(0.54)$ & $1008(0.04)$ & 624,036 \\
\hline 28 & Henry Moore & Modern & $623,510,656(0.53)$ & $4350(0.17)$ & 143,336 \\
\hline 29 & Paul Gauguin & OldMasters & $607,289,600(0.52)$ & $928(0.04)$ & 654,407 \\
\hline 30 & Camille Pissarro & OldMasters & $604,985,536(0.52)$ & $1882(0.07)$ & 321,459 \\
\hline 31 & Vincent Van Gogh & OldMasters & $597,029,632(0.51)$ & $153(0.01)$ & $3,902,155$ \\
\hline 32 & Gustav Klimt & OldMasters & $575,096,128(0.49)$ & $827(0.03)$ & 695,400 \\
\hline 33 & Edvard Munch & OldMasters & $563,149,632(0.48)$ & $1695(0.07)$ & 332,242 \\
\hline 34 & Jean Dubuffet & Modern & $553,278,464(0.47)$ & $2291(0.09)$ & 241,501 \\
\hline 35 & Wassily Kandinsky & OldMasters & $505,244,672(0.43)$ & $1091(0.04)$ & 463,102 \\
\hline 36 & Auguste Rodin & OldMasters & $501,098,080(0.43)$ & $1695(0.07)$ & 295,633 \\
\hline 37 & Christopher Wool & Contemporary & $484,130,208(0.41)$ & $532(0.02)$ & 910,019 \\
\hline 38 & Lucian Freud & Postwar & $482,981,248(0.41)$ & $553(0.02)$ & 873,384 \\
\hline 39 & Richard Prince & Contemporary & $463,410,368(0.39)$ & $1066(0.04)$ & 434,719 \\
\hline 40 & Null Chu Teh-Chun & Postwar & $463,145,696(0.39)$ & $1521(0.06)$ & 304,501 \\
\hline 41 & Kees Van Dongen & Modern & $452,388,320(0.39)$ & $1719(0.07)$ & 263,170 \\
\hline
\end{tabular}


Table 1 (continued)

\begin{tabular}{llllll}
\hline Rank & Artist & Movement & Total sales value in \$ & $\begin{array}{l}\text { Total sales volume } \\
(\text { market share }(\%))\end{array}$ & Average price \\
\hline 42 & Salvador Dalí & Modern & $381,447,968(0.33)$ & $10,991(0.43)$ & 34,705 \\
43 & Paul Signac & OldMasters & $365,125,984(0.31)$ & $1267(0.05)$ & 288,182 \\
44 & Pierre Bonnard & OldMasters & $358,641,664(0.31)$ & $1758(0.07)$ & 204,006 \\
45 & Chaïm Soutine & Modern & $353,786,048(0.3)$ & $169(0.01)$ & $2,093,409$ \\
46 & Peter Doig & Contemporary & $351,808,064(0.3)$ & $612(0.02)$ & 574,850 \\
47 & Alfred Sisley & OldMasters & $349,061,056(0.3)$ & $285(0.01)$ & $1,224,776$ \\
48 & Ed Ruscha & Contemporary & $343,948,960(0.29)$ & $2068(0.08)$ & 166,320 \\
49 & Jackson Pollock & Postwar & $343,908,544(0.29)$ & $148(0.01)$ & $2,323,707$ \\
50 & Donald Judd & Postwar & $341,338,528(0.29)$ & $917(0.04)$ & 372,234 \\
\hline
\end{tabular}

All prices are in constant 2017 \$

\subsection{Performance at auction}

Table 4 reports the results of our baseline regression. The coefficient on the female dummy shows that, controlling for artwork characteristics, artworks by female artists are on average $4.4 \%$ more expensive than the artworks of male artists. All other coefficients are in line with expectations. Sculptures are the most expensive objects, while prints and multiples are least expensive relative to paintings. Artworks of artists from Southern Europe sell at higher prices. ${ }^{16}$ Lastly, artworks of living artists sell for less (negative coefficient on the 'Alive' dummy variable). The R-squared of the regression is 0.42 which is within the usual range for hedonic models in the art market literature (Ashenfelter and Graddy 2002). We also run regressions for different types of art categories (Columns 2 to 6, Table 4). With the exception of two categories-1) Design and 2) Prints and Multiples-every object type has a positive coefficient associated with the female dummy. Paintings produced by female artists, the most prevalent type of object, are $15.5 \%$ more expensive than paintings with comparable characteristics that are controlled for in our regressions, produced by male artists.

We re-estimate the model for each artistic movement separately. Table 5 shows that the coefficient on the female dummy is positive and statistically significant for each movement with the exception of Contemporary art, where we observe a negative coefficient. The price difference on lots by Contemporary female artists, where we encounter a relatively larger proportion of women $(9.3 \%)$, is $-8.3 \% .^{17}$

\footnotetext{
${ }^{16}$ Highly renowned artists such as Picasso, Giacometti, Modigliani, Miro and Fontana, among many others are included in the category.

17 To further homogenize our sample, we also consider every cohort (generation) of artists separately and run regressions for each generation of artists whereby one generation is defined as a time period of 25 years. The results are presented in Table 11 in Appendix. Consistent with the previous results, we observe a positive price difference for female lots for the generations active before the year 1850 and a negative price difference for more recent generations born after 1950.
} 
Table 2 Top 50 female artists by value of sales

\begin{tabular}{|c|c|c|c|c|c|}
\hline Rank & Artist & Movement & $\begin{array}{l}\text { Total sales value } \\
\text { in } \$ \text { (market share } \\
(\%))\end{array}$ & $\begin{array}{l}\text { Total sales volume } \\
(\text { market share }(\%))\end{array}$ & Average price \\
\hline 1 & Joan Mitchell & Postwar & $392,962,816(9.59)$ & $641(0.61)$ & $613,046.50$ \\
\hline 2 & Georgia O’Keeffe & Modern & $211,702,064(5.17)$ & $117(0.11)$ & $1,809,419.00$ \\
\hline 3 & Louise Bourgeois & Postwar & $197,968,512(4.83)$ & $649(0.62)$ & $305,036.20$ \\
\hline 4 & Agnes Martin & Postwar & $193,711,040(4.73)$ & $296(0.28)$ & $654,429.20$ \\
\hline 5 & Cindy Sherman & Contemporary & $140,606,176(3.43)$ & $1269(1.21)$ & $110,800.80$ \\
\hline 6 & Barbara Hepworth & Modern & $135,153,952(3.3)$ & $616(0.59)$ & $219,405.80$ \\
\hline 7 & Tamara De Lempicka & Modern & $127,470,128(3.11)$ & $313(0.3)$ & $407,252.80$ \\
\hline 8 & $\begin{array}{l}\text { Natalia Sergeevna } \\
\text { Goncharova }\end{array}$ & Modern & $127,109,512(3.1)$ & $731(0.7)$ & $173,884.40$ \\
\hline 9 & Mary Cassatt & OldMasters & $88,247,688(2.15)$ & $832(0.79)$ & $106,066.90$ \\
\hline 10 & Helen Frankenthaler & Postwar & $79,406,904$ (1.94) & $1100(1.05)$ & $72,188.09$ \\
\hline 11 & Bridget Riley & Contemporary & $78,610,368(1.92)$ & $818(0.78)$ & $96,100.70$ \\
\hline 12 & Berthe Morisot & OldMasters & $76,978,256(1.88)$ & $258(0.25)$ & $298,365.30$ \\
\hline 13 & Eileen Gray & Modern & $75,399,800(1.84)$ & $187(0.18)$ & $403,207.50$ \\
\hline 14 & Gabriele Münter & Modern & $67,722,952(1.65)$ & $449(0.43)$ & $150,830.60$ \\
\hline 15 & Niki De Saint Phalle & Postwar & $67,633,304(1.65)$ & $1849(1.76)$ & $36,578.32$ \\
\hline 16 & $\begin{array}{l}\text { Maria Helena Vieira } \\
\text { Da Silva }\end{array}$ & Modern & $62,461,532(1.53)$ & $683(0.65)$ & $91,451.73$ \\
\hline 17 & Elisabeth Frink & Postwar & $56,816,528(1.39)$ & $1212(1.16)$ & $46,878.32$ \\
\hline 18 & Camille Claudel & OldMasters & $47,351,292(1.16)$ & $115(0.11)$ & $411,750.40$ \\
\hline 19 & Julie Mehretu & Contemporary & $39,050,448(0.95)$ & $117(0.11)$ & $333,764.50$ \\
\hline 20 & Marie Laurencin & Modern & $37,916,940(0.93)$ & $1633(1.56)$ & $23,219.19$ \\
\hline 21 & Germaine Richier & Modern & $36,489,668(0.89)$ & $207(0.2)$ & $176,278.60$ \\
\hline 22 & Charlotte Perriand & Modern & $36,297,372(0.89)$ & $1270(1.21)$ & $28,580.61$ \\
\hline 23 & Sonia Delaunay & Modern & $35,823,440(0.87)$ & $2414(2.3)$ & $14,839.87$ \\
\hline 24 & $\begin{array}{l}\text { Zinaida Evgenievna } \\
\text { Serebryakova }\end{array}$ & Modern & $35,679,896(0.87)$ & $130(0.12)$ & $274,460.80$ \\
\hline 25 & Elizabeth Peyton & Contemporary & $34,532,152(0.84)$ & $305(0.29)$ & $113,220.20$ \\
\hline 26 & Jenny Saville & Contemporary & $33,717,704(0.82)$ & $67(0.06)$ & $503,249.30$ \\
\hline 27 & Lee Krasner & Modern & $32,803,988(0.8)$ & $125(0.12)$ & $262,431.90$ \\
\hline 28 & Louise Nevelson & Modern & $31,701,858(0.77)$ & $995(0.95)$ & $31,861.16$ \\
\hline 29 & Eva Hesse & Postwar & $31,495,010(0.77)$ & $67(0.06)$ & $470,074.80$ \\
\hline 30 & Rosemarie Trockel & Contemporary & $29,649,818(0.72)$ & $370(0.35)$ & $80,134.64$ \\
\hline 31 & Leonora Carrington & Postwar & $29,199,762(0.71)$ & $368(0.35)$ & $79,347.18$ \\
\hline 32 & Diane Arbus & Postwar & $27,909,234(0.68)$ & $680(0.65)$ & $41,042.99$ \\
\hline 33 & Cady Noland & Contemporary & $27,686,520(0.68)$ & $50(0.05)$ & $553,730.40$ \\
\hline 34 & Line Vautrin & Postwar & $27,666,570(0.68)$ & $1390(1.33)$ & $19,904.01$ \\
\hline 35 & Käthe Kollwitz & OldMasters & $27,358,426(0.67)$ & $3287(3.14)$ & $8,323.22$ \\
\hline 36 & Tauba Auerbach & Contemporary & $24,741,638(0.6)$ & $115(0.11)$ & $215,144.70$ \\
\hline 37 & Elaine Sturtevant & Postwar & $24,650,568(0.6)$ & $109(0.1)$ & $226,152.00$ \\
\hline 38 & Paula Rego & Contemporary & $22,420,256(0.55)$ & $279(0.27)$ & $80,359.34$ \\
\hline
\end{tabular}


Table 2 (continued)

\begin{tabular}{llllll}
\hline Rank & Artist & Movement & $\begin{array}{l}\text { Total sales value } \\
\text { in } \$(\text { market share } \\
(\%))\end{array}$ & $\begin{array}{l}\text { Total sales volume } \\
(\text { market share }(\%))\end{array}$ & Average price \\
\hline 39 & Grandma Moses & OldMasters & $20,810,438(0.51)$ & $228(0.22)$ & $91,273.85$ \\
40 & Alexandra Exter & Modern & $20,683,992(0.51)$ & $214(0.2)$ & $96,654.17$ \\
41 & Paula Modersohn- & Modern & $20,028,110(0.49)$ & $227(0.22)$ & $88,229.56$ \\
& Becker & Contemporary & $17,710,106(0.43)$ & $207(0.2)$ & $85,556.07$ \\
42 & Barbara Kruger & Contemporary & $16,430,324(0.4)$ & $153(0.15)$ & $107,387.70$ \\
43 & Sherrie Levine & Modern & $16,238,367(0.4)$ & $42(0.04)$ & $386,627.80$ \\
44 & Remedios Varo & Contemporary & $16,097,871(0.39)$ & $121(0.12)$ & $133,040.30$ \\
45 & Lisa Yuskavage & Modern & $16,033,746(0.39)$ & $119(0.11)$ & $134,737.40$ \\
46 & Alice Neel & Postwar & $15,410,404(0.38)$ & $79(0.08)$ & $195,068.40$ \\
47 & Ruth Asawa & Contemporary & $15,272,947(0.37)$ & $485(0.46)$ & $31,490.61$ \\
48 & Tracey Emin & Postwar & $14,461,859(0.35)$ & $1098(1.05)$ & $13,171.09$ \\
49 & Mary Fedden & OldMasters & $14,241,870(0.35)$ & $323(0.31)$ & $44,092.48$ \\
50 & Angelika Kauffmann & Old &
\end{tabular}

All prices are in constant 2017 \$.

The post-war era yields the largest positive price difference $(+14.9 \%)$ for artworks by female artists. This movement is associated with a number of highly recognized female artists (i.e., Agnes Martin, Helen Frankenthaler and Joan Mitchell).

Lastly, we investigate the persistence of the difference in performance found in our baseline regression for the period since the Millennium. We split our data into four different time periods for which we run separate regressions (Table 6). For all four periods, a positive price difference for female lots persists ranging from $+1.9 \%$ to $+7.4 \%$. This effect is robust across different object types and over time.

\subsection{The top end}

Table 7 shows that after the 99.97th quantile, which represents the top 40 artists in terms of total sales value, there are no women. This quantile corresponds to a market share of $40 \%$ in terms of value. To more closely analyze differences in the prices for male and female artists at the top end of the market, we create a sub-sample for artworks selling for more than $\$ 1$ million at auction (denoted as mega transactions). ${ }^{18}$ We perform a separate analysis for the full sample (columns 1 and 2) and the contemporary sub-sample (columns 3 and 4). Controlling for artwork characteristics,

\footnotetext{
18 As a result, in the subsequent regression, the left-hand-side variable is censored. We also performed a nonparametric test by running a quantile regression where we obtained consistent results (available upon request).
} 


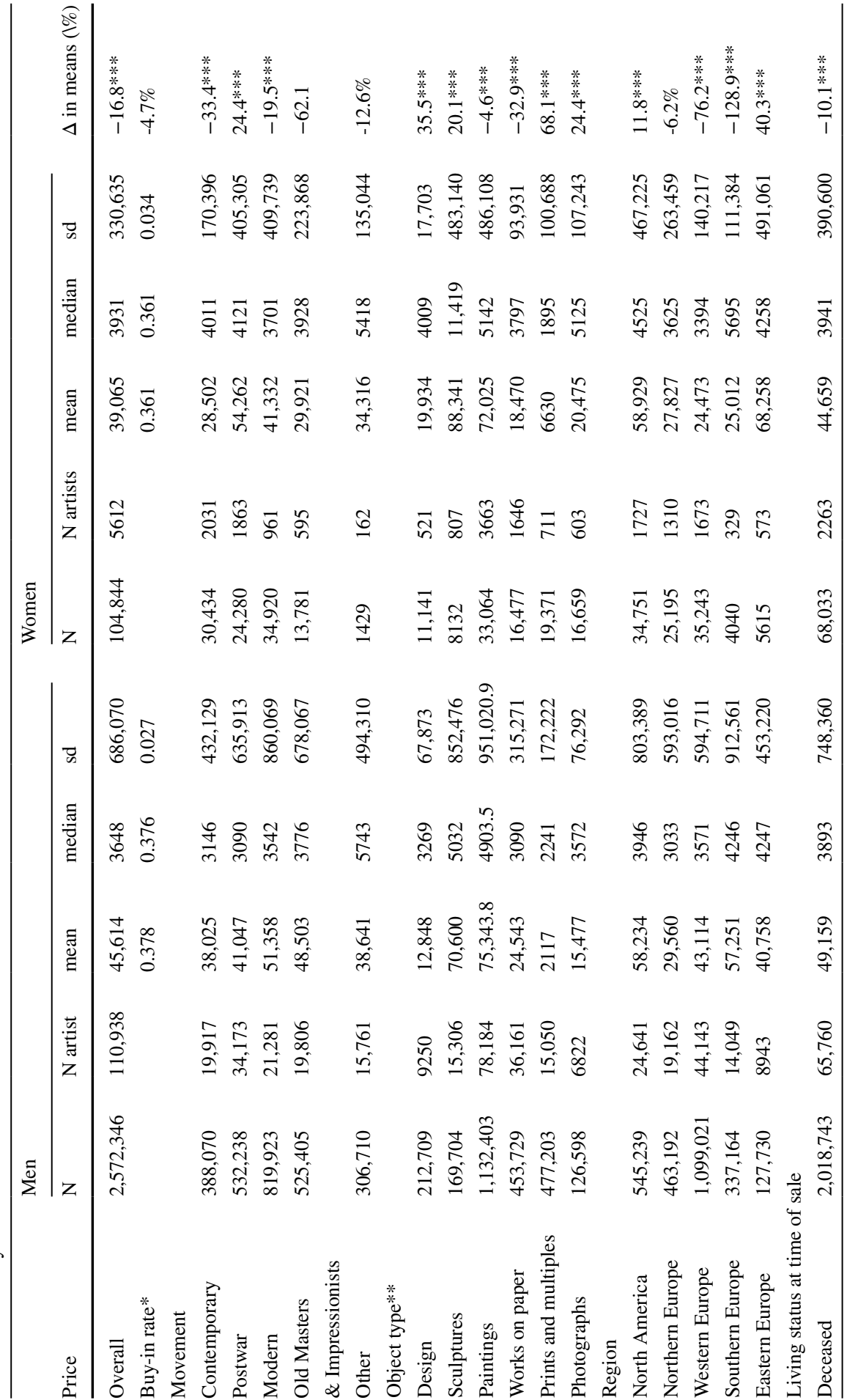




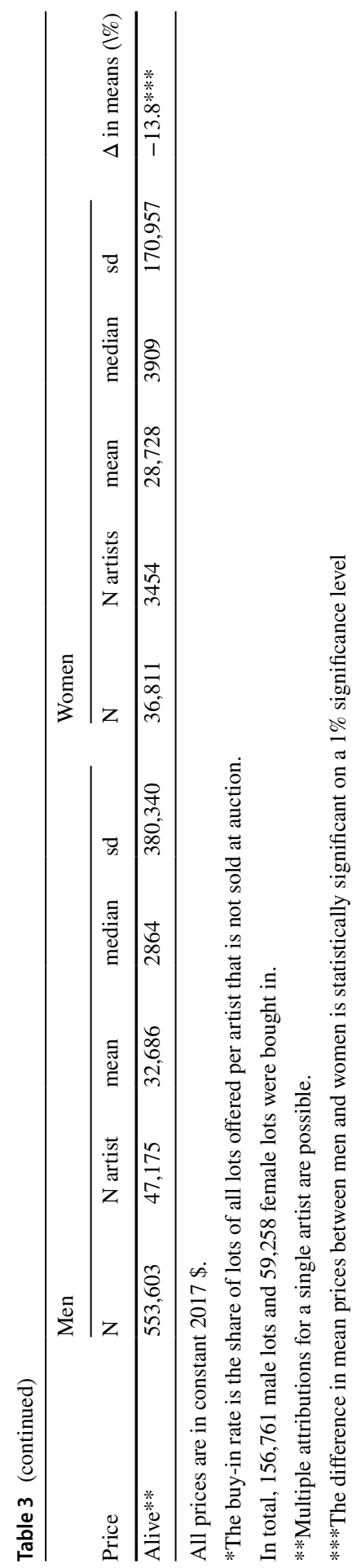




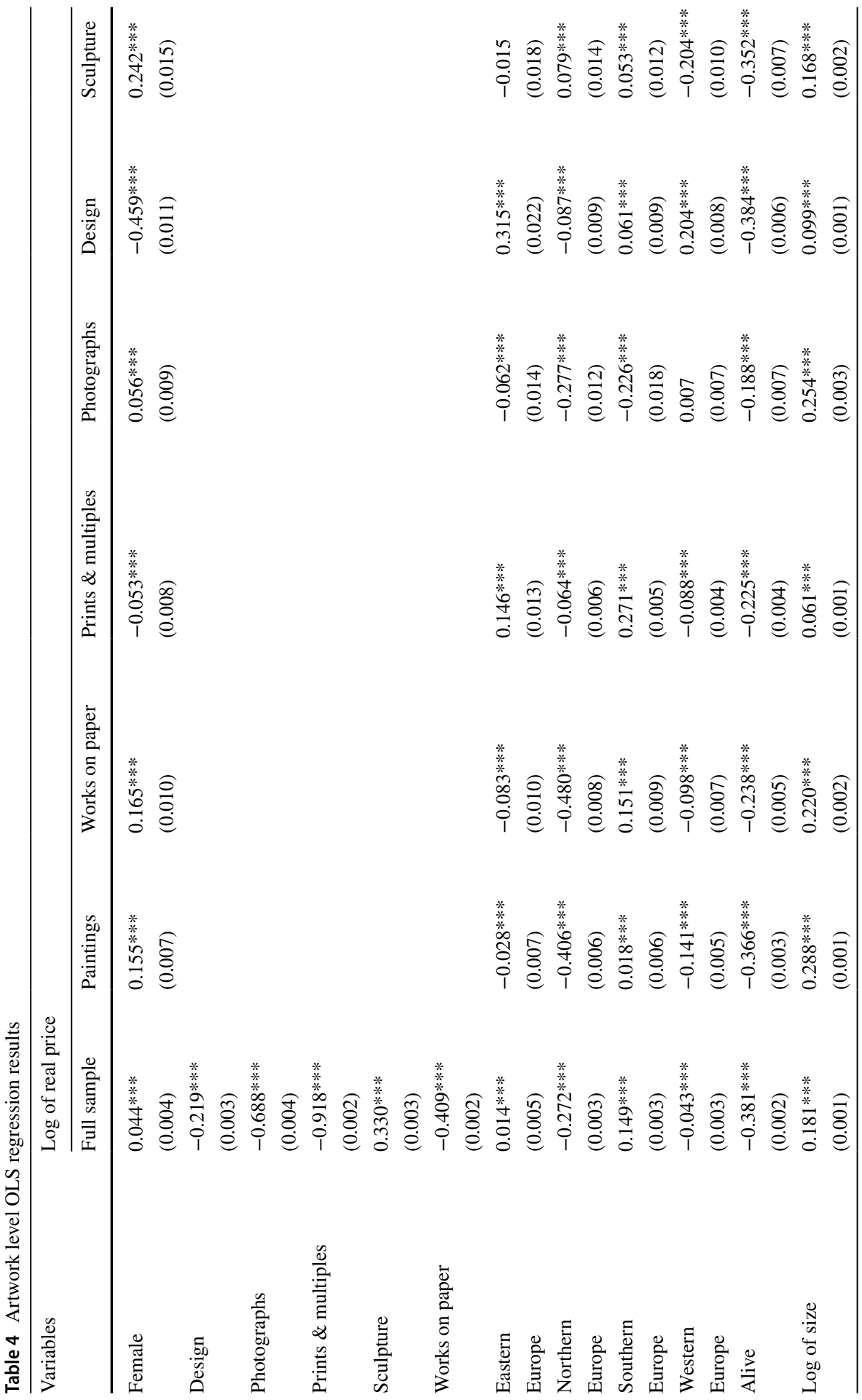




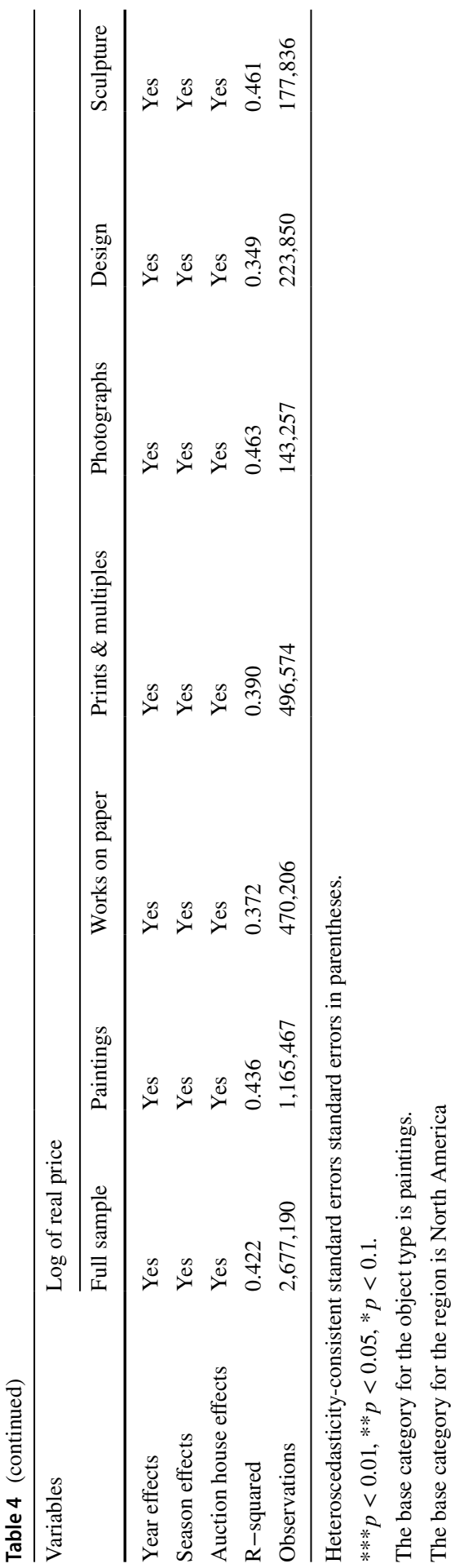


Table 5 Artwork level OLS regression results—by movement

\begin{tabular}{|c|c|c|c|c|}
\hline \multirow[t]{2}{*}{ Variables } & \multicolumn{4}{|c|}{ Log of real price } \\
\hline & Old Masters & Modern & Post-war & Contemporary \\
\hline Female & $\begin{array}{l}0.100 * * * \\
(0.011)\end{array}$ & $\begin{array}{l}0.045^{* * *} \\
(0.007)\end{array}$ & $\begin{array}{l}0.149 * * * \\
(0.008)\end{array}$ & $\begin{array}{l}-0.083 * * * \\
(0.007)\end{array}$ \\
\hline Design & $\begin{array}{l}-0.012 \\
(0.009)\end{array}$ & $\begin{array}{l}-0.199 * * * \\
(0.006)\end{array}$ & $\begin{array}{l}-0.261^{* * * *} \\
(0.006)\end{array}$ & $\begin{array}{l}-0.168 * * * \\
(0.009)\end{array}$ \\
\hline Photographs & $\begin{array}{l}-0.707 * * * \\
(0.014)\end{array}$ & $\begin{array}{l}-0.788^{* * *} \\
(0.007)\end{array}$ & $\begin{array}{l}-0.718^{* * *} \\
(0.008)\end{array}$ & $\begin{array}{l}-0.494 * * * \\
(0.007)\end{array}$ \\
\hline Prints \& multiples & $\begin{array}{l}-0.897 * * * \\
(0.006)\end{array}$ & $\begin{array}{l}-1.017 * * * \\
(0.004)\end{array}$ & $\begin{array}{l}-0.962^{* * *} \\
(0.005)\end{array}$ & $\begin{array}{l}-0.804 * * * \\
(0.006)\end{array}$ \\
\hline Sculpture & $\begin{array}{l}0.322 * * * \\
(0.008)\end{array}$ & $\begin{array}{l}0.406^{* * * *} \\
(0.007)\end{array}$ & $\begin{array}{l}0.341 * * * \\
(0.007)\end{array}$ & $\begin{array}{l}0.393 * * * \\
(0.007)\end{array}$ \\
\hline Works on paper & $\begin{array}{l}-0.379 * * * \\
(0.005)\end{array}$ & $\begin{array}{l}-0.383 * * * \\
(0.004)\end{array}$ & $\begin{array}{l}-0.371^{* * * *} \\
(0.005)\end{array}$ & $\begin{array}{l}-0.325^{* * * *} \\
(0.006)\end{array}$ \\
\hline Eastern Europe & $\begin{array}{l}0.441 * * * \\
(0.010)\end{array}$ & $\begin{array}{l}0.168 * * * \\
(0.007)\end{array}$ & $\begin{array}{l}-0.528 * * * \\
(0.011)\end{array}$ & $\begin{array}{l}-0.359 * * * \\
(0.012)\end{array}$ \\
\hline Northern Europe & $\begin{array}{l}-0.228 * * * \\
(0.008)\end{array}$ & $\begin{array}{l}-0.130 * * * \\
(0.006)\end{array}$ & $\begin{array}{l}-0.497 * * * \\
(0.006)\end{array}$ & $\begin{array}{l}-0.057 * * * \\
(0.007)\end{array}$ \\
\hline Southern Europe & $\begin{array}{l}0.107 * * * \\
(0.010)\end{array}$ & $\begin{array}{l}0.539 * * * \\
(0.006)\end{array}$ & $\begin{array}{l}-0.228 * * * \\
(0.007)\end{array}$ & $\begin{array}{l}-0.085^{* * * *} \\
(0.008)\end{array}$ \\
\hline Western Europe & $\begin{array}{l}0.010 \\
(0.006)\end{array}$ & $\begin{array}{l}0.120 * * * \\
(0.005)\end{array}$ & $\begin{array}{l}-0.284 * * * \\
(0.005)\end{array}$ & $\begin{array}{l}-0.100 * * * \\
(0.006)\end{array}$ \\
\hline Alive & & & $\begin{array}{l}-0.370 * * * \\
(0.004)\end{array}$ & \\
\hline Log of size & $\begin{array}{l}0.186^{* * * *} \\
(0.001)\end{array}$ & $\begin{array}{l}0.144 * * * \\
(0.001)\end{array}$ & $\begin{array}{l}0.188 * * * \\
(0.001)\end{array}$ & $\begin{array}{l}0.240^{* * * *} \\
(0.001)\end{array}$ \\
\hline Year Effects & Yes & Yes & Yes & Yes \\
\hline Season Effects & Yes & Yes & Yes & Yes \\
\hline Auction house & Yes & Yes & Yes & Yes \\
\hline R-squared & 0.420 & 0.417 & 0.437 & 0.483 \\
\hline Observations & 539,186 & 854,843 & 556,518 & 418,504 \\
\hline
\end{tabular}

Heteroscedasticity-consistent standard errors standard errors in parentheses.

$* * * p<0.01, * * p<0.05, * p<0.1$.

The base category for the object type is paintings.

The base category for the region is North America.

There are 189 photographs in the Old Masters sample

the regression results in Table 8 show that within the price category of $\$ 1$ million and above, artworks created by men sell at prices, on average $18.4 \%$ higher, than the works of women. The price difference is $17.9 \%$ higher when we consider the subsample of contemporary artists. 
Table 6 Artwork level OLS regression results—by time period

\begin{tabular}{|c|c|c|c|c|}
\hline \multirow[t]{2}{*}{ Variables } & \multicolumn{4}{|c|}{ Log of real price } \\
\hline & 2000-2004 & $2005-2009$ & 2010-2014 & 2015-2017 \\
\hline Female & $\begin{array}{l}0.074 * * * \\
(0.009)\end{array}$ & $\begin{array}{l}0.069 * * * \\
(0.007)\end{array}$ & $\begin{array}{l}0.019 * * * \\
(0.006)\end{array}$ & $\begin{array}{l}0.039 * * * \\
(0.013)\end{array}$ \\
\hline Design & $\begin{array}{l}-0.425^{* * *} \\
(0.021)\end{array}$ & $\begin{array}{l}-0.207 * * * \\
(0.007)\end{array}$ & $\begin{array}{l}-0.200^{* * * *} \\
(0.005)\end{array}$ & $\begin{array}{l}-0.186 * * * \\
(0.011)\end{array}$ \\
\hline Photographs & $\begin{array}{l}-0.945^{* * *} \\
(0.009)\end{array}$ & $\begin{array}{l}-0.722^{* * *} \\
(0.007)\end{array}$ & $\begin{array}{l}-0.563^{* * *} \\
(0.006)\end{array}$ & $\begin{array}{l}-0.570 * * * \\
(0.014)\end{array}$ \\
\hline Prints \& multiples & $\begin{array}{l}-1.175^{* * *} \\
(0.005)\end{array}$ & $\begin{array}{l}-1.074 * * * \\
(0.004)\end{array}$ & $\begin{array}{l}-0.736 \text { *** } \\
(0.004)\end{array}$ & $\begin{array}{l}-0.661 * * * \\
(0.009)\end{array}$ \\
\hline Sculpture & $\begin{array}{l}0.406 * * * \\
(0.008)\end{array}$ & $\begin{array}{l}0.444 * * * \\
(0.007)\end{array}$ & $\begin{array}{l}0.289 * * * \\
(0.005)\end{array}$ & $\begin{array}{l}0.190^{* * * *} \\
(0.011)\end{array}$ \\
\hline Works on paper & $\begin{array}{l}-0.439 * * * \\
(0.005)\end{array}$ & $\begin{array}{l}-0.448 * * * \\
(0.004)\end{array}$ & $\begin{array}{l}-0.378^{* * *} \\
(0.004)\end{array}$ & $\begin{array}{l}-0.346^{* * *} \\
(0.008)\end{array}$ \\
\hline Eastern Europe & $\begin{array}{l}-0.016 \\
(0.012)\end{array}$ & $\begin{array}{l}0.140 * * * \\
(0.008)\end{array}$ & $\begin{array}{l}0.000 \\
(0.007)\end{array}$ & $\begin{array}{l}-0.138^{* * *} \\
(0.015)\end{array}$ \\
\hline Northern Europe & $\begin{array}{l}-0.260 * * * \\
(0.007)\end{array}$ & $\begin{array}{l}-0.264 * * * \\
(0.006)\end{array}$ & $\begin{array}{l}-0.247 * * * \\
(0.005)\end{array}$ & $\begin{array}{l}-0.273 * * * \\
(0.011)\end{array}$ \\
\hline Southern Europe & $\begin{array}{l}0.242 * * * \\
(0.007)\end{array}$ & $\begin{array}{l}0.188^{* * *} \\
(0.006)\end{array}$ & $\begin{array}{l}0.095 * * * \\
(0.005)\end{array}$ & $\begin{array}{l}0.083 * * * \\
(0.011)\end{array}$ \\
\hline Western Europe & $\begin{array}{l}0.012^{* *} \\
(0.006)\end{array}$ & $\begin{array}{l}-0.049^{* * *} \\
(0.005)\end{array}$ & $\begin{array}{l}-0.048^{* * * *} \\
(0.004)\end{array}$ & $\begin{array}{l}-0.084 * * * \\
(0.009)\end{array}$ \\
\hline Alive & $\begin{array}{l}-0.487 * * * \\
(0.005)\end{array}$ & $\begin{array}{l}-0.397 * * * \\
(0.004)\end{array}$ & $\begin{array}{l}-0.357 \text { *** } \\
(0.003)\end{array}$ & $\begin{array}{l}-0.279 * * * \\
(0.007)\end{array}$ \\
\hline Log of size & $\begin{array}{l}0.201 * * * \\
(0.001)\end{array}$ & $\begin{array}{l}0.204 * * * \\
(0.001)\end{array}$ & $\begin{array}{l}0.167 * * * \\
(0.001)\end{array}$ & $\begin{array}{l}0.147 * * * \\
(0.002)\end{array}$ \\
\hline Year effects & Yes & Yes & Yes & Yes \\
\hline Season effects & Yes & Yes & Yes & Yes \\
\hline Auction house effects & Yes & Yes & Yes & Yes \\
\hline R-squared & 0.452 & 0.443 & 0.424 & 0.402 \\
\hline Observations & 496,923 & 756,668 & $1,026,029$ & 209,830 \\
\hline
\end{tabular}

Heteroscedasticity-consistent standard errors standard errors in parentheses.

$* * * p<0.01,{ }^{* *} p<0.05, * p<0.1$.

The base category for the object type is paintings.

The base category for the region is North America

\subsection{Auction participation}

So far, we have only considered the (secondary) auction market which represents the market for established artists. To investigate potential sources of the observed differences in prices paid for male and female generated artworks, we look at the (primary) gallery market, which impacts an artist's chance to be represented at auction. A gallery provides the artists with access to its network of buyers and promotes them. We 
Table 7 Quantiles by total sales value for men and women

\begin{tabular}{|c|c|c|c|c|c|}
\hline \multirow[b]{2}{*}{ Quantile } & \multirow[b]{2}{*}{ Total sales value $(\$)$} & \multicolumn{2}{|l|}{ Men } & \multicolumn{2}{|l|}{ Women } \\
\hline & & $\mathrm{N}$ artists & Cumulative & $\mathrm{N}$ artists & Cumulative \\
\hline$>99.97 \%$ & & $0.03 \%(40)$ & $0.03 \%$ & $0.00 \%(0)$ & $0.00 \%$ \\
\hline$<99.97 \%$ & $452,388,320$ & $0.01 \%(17)$ & $0.05 \%$ & $0.02 \%(1)$ & $0.02 \%$ \\
\hline$<99.96 \%$ & $351,808,064$ & $0.04 \%$ & $0.08 \%$ & $0.05 \%(3)$ & $0.07 \%$ \\
\hline$<99.1 \%$ & $176,461,520$ & $0.90 \%(994)$ & $0.98 \%$ & $1.19 \%(67)$ & $1.27 \%$ \\
\hline$<99 \%$ & $9,461,848$ & $4.05 \%(4490)$ & $5.03 \%$ & $3.06 \%(172)$ & $4.33 \%$ \\
\hline$<95 \%$ & 982,622 & $5.09 \%(5650)$ & $10.12 \%$ & $3.17 \%(178)$ & $7.50 \%$ \\
\hline$<90 \%$ & 312,493 & $15.24 \%(16,908)$ & $25.36 \%$ & $10.23 \%(574)$ & $17.73 \%$ \\
\hline$<75 \%$ & 50,209 & $25.19 \%(27,949)$ & $50.56 \%$ & $21.19 \%(1189)$ & $38.92 \%$ \\
\hline$<50 \%$ & 8604 & $24.92 \%(27,644)$ & $75.48 \%$ & $26.60 \%(1493)$ & $65.52 \%$ \\
\hline$<25 \%$ & 2089 & $14.82 \%(16,442)$ & $90.30 \%$ & $18.55 \%(1041)$ & $84.07 \%$ \\
\hline$<10 \%$ & 814 & $4.90 \%(5435)$ & $95.20 \%$ & $6.99 \%(392)$ & $91.05 \%$ \\
\hline$<5 \%$ & 545 & $4.80 \%(5326)$ & $100.00 \%$ & $8.95 \%(502)$ & $100.00 \%$ \\
\hline Total sales value & $121,431,023,957$ & & & & \\
\hline
\end{tabular}

use artnet's gallery database covering representation for 4754 contemporary artists. Table 9 shows that out of 4180 male artists, 96.9\% (4050 artists) can also be found in the auction market sample. However, only 93\% (534 artists) out of the 574 female artists made this transition. ${ }^{19}$ We analyze the likelihood of women to move from the primary into the secondary market in a multivariate setting using a Probit model on the primary market sample. The binary dependent variable indicates whether an artist from the gallery sample is traded at auction. We include the female dummy and control for artist's nationality, birth year and a dummy for every gallery an artist is represented by. The coefficient on the female dummy indicates that female artists are $2.2 \%$ less likely to participate at auction compared to their male counterparts (Table 10). ${ }^{20}$

\section{Concluding remarks}

Our study shows that females comprise less than $4 \%$ of art auction sales, as identified by their birth sex. Furthermore, we show that artworks by females are, on average, sold for 4.4\% more than artworks by males, after controlling for artwork and artist characteristics. These findings are consistent with a recent study by Cameron et al. (2017) who find a premium for female artworks traded at auction within a small sample of Yale graduates. At the same time, we provide evidence of average lower prices for the artworks of contemporary female artists as well as for artworks selling at the top-end of the market. Overall this analysis highlights how the share of females, as observed by birth-identified sex, is gaining in market share as the market evolves, and subsequently that price

\footnotetext{
19 The difference in proportions test is statistically significant at a $1 \%$ level.

20 The presented coefficients are the marginal effects at the mean.
} 
Table 8 Artwork level OLS regression results-mega transactions

\begin{tabular}{|c|c|c|c|c|}
\hline \multirow[t]{3}{*}{ Variables } & \multicolumn{4}{|l|}{ Log of real price } \\
\hline & Full sample & Full sample & Contemporary & Contemporary \\
\hline & $\begin{array}{l}\text { Mega transac- } \\
\text { tions }\end{array}$ & $\begin{array}{l}\text { Excl. mega transac- } \\
\text { tions }\end{array}$ & Mega transactions & $\begin{array}{l}\text { Excl. mega trans- } \\
\text { actions }\end{array}$ \\
\hline Female & $\begin{array}{l}-0.184 * * * \\
(0.033)\end{array}$ & $\begin{array}{l}0.046 * * * \\
(0.004)\end{array}$ & $\begin{array}{l}-0.179 * * \\
(0.073)\end{array}$ & $\begin{array}{l}-0.053 * * * \\
(0.007\end{array}$ \\
\hline Design & $\begin{array}{l}-0.317 * * * \\
(0.068)\end{array}$ & $\begin{array}{l}-0.192 * * * \\
(0.003)\end{array}$ & $\begin{array}{l}-0.316 \\
(0.250)\end{array}$ & $\begin{array}{l}-0.146^{* * * *} \\
(0.009)\end{array}$ \\
\hline Photographs & $\begin{array}{l}-0.333 * * * \\
(0.074)\end{array}$ & $\begin{array}{l}-0.627 * * * \\
(0.004)\end{array}$ & $\begin{array}{l}-0.361^{* * *} \\
(0.075)\end{array}$ & $\begin{array}{l}-0.445^{* * *} \\
(0.006)\end{array}$ \\
\hline Prints \& multiples & $\begin{array}{l}-0.265^{* * *} \\
(0.060)\end{array}$ & $\begin{array}{l}-0.869 * * * \\
(0.002)\end{array}$ & $\begin{array}{l}-0.350 * * * \\
(0.131)\end{array}$ & $\begin{array}{l}-0.759 * * * \\
(0.006)\end{array}$ \\
\hline Sculpture & $\begin{array}{l}-0.028 \\
(0.022)\end{array}$ & $\begin{array}{l}0.318 * * * \\
(0.003)\end{array}$ & $\begin{array}{l}0.050 \\
(0.041)\end{array}$ & $\begin{array}{l}0.385^{* * *} \\
(0.007)\end{array}$ \\
\hline Works on paper & $\begin{array}{l}-0.229 * * * \\
(0.025)\end{array}$ & $\begin{array}{l}-0.381 * * * \\
(0.002)\end{array}$ & $\begin{array}{l}-0.315^{* * * *} \\
(0.081)\end{array}$ & $\begin{array}{l}-0.300 * * * \\
(0.006)\end{array}$ \\
\hline Eastern Europe & $\begin{array}{l}0.004 \\
(0.034)\end{array}$ & $\begin{array}{l}0.021 * * * \\
(0.004)\end{array}$ & $\begin{array}{l}0.058 \\
(0.146)\end{array}$ & $\begin{array}{l}-0.337 * * * \\
(0.011)\end{array}$ \\
\hline Northern Europe & $\begin{array}{l}0.076 * * * \\
(0.025)\end{array}$ & $\begin{array}{l}-0.256 * * * \\
(0.003)\end{array}$ & $\begin{array}{l}-0.101 * * \\
(0.045)\end{array}$ & $\begin{array}{l}-0.052 * * * \\
(0.007)\end{array}$ \\
\hline Southern Europe & $\begin{array}{l}0.136 * * * \\
(0.022)\end{array}$ & $\begin{array}{l}0.142 * * * \\
(0.003)\end{array}$ & $\begin{array}{l}-0.268 * * * \\
(0.064)\end{array}$ & $\begin{array}{l}-0.078 * * * \\
(0.008)\end{array}$ \\
\hline Western Europe & $\begin{array}{l}-0.281^{* * * *} \\
(0.019)\end{array}$ & $\begin{array}{l}-0.368 * * * \\
(0.002)\end{array}$ & $\begin{array}{l}0.197 * * * \\
(0.041)\end{array}$ & $\begin{array}{l}-0.104 * * * \\
(0.006)\end{array}$ \\
\hline Alive & $\begin{array}{l}-0.487 * * * \\
(0.005)\end{array}$ & $\begin{array}{l}-0.397 * * * \\
(0.004)\end{array}$ & & \\
\hline Log of size & $\begin{array}{l}0.084 * * * \\
(0.005)\end{array}$ & $\begin{array}{l}0.169 * * * \\
(0.001)\end{array}$ & $\begin{array}{l}0.096 * * * \\
(0.012)\end{array}$ & $\begin{array}{l}0.228 * * * \\
(0.001)\end{array}$ \\
\hline Year effects & Yes & Yes & Yes & Yes \\
\hline Season effects & Yes & Yes & Yes & Yes \\
\hline Auction house effects & Yes & Yes & Yes & Yes \\
\hline R-squared & 0.095 & 0.410 & 0.138 & 0.472 \\
\hline Observations & 15,881 & $2,661,309$ & 2270 & 416,234 \\
\hline
\end{tabular}

Heteroscedasticity-consistent standard errors standard errors in parentheses

$* * * p<0.01, * * p<0.05, * p<0.1$.

Mega transactions are defined as transaction above \$1,000,000 in real 2017 USD.

The base category for the object type is paintings.

The base category for the region is North America

differences observed between male and female artworks are reflected in a difference in artistic characteristics of female produced artworks. Our results call for further investigation into the supply and demand factors that prevail in the market that might explain observed differences in prices paid for male and female produced artworks. 
Table 9 Summary statistics for men and women: primary market sample

\begin{tabular}{lllllllll}
\hline Variables & \multicolumn{2}{l}{ Men } & & & & Women & \\
\cline { 2 - 3 } \cline { 6 - 8 } & $\mathrm{N}$ & Mean & $\mathrm{SD}$ & & $\mathrm{N}$ & Mean & SD \\
\hline Auction participation & $4180(4050)$ & $0.969 * * *$ & 0.174 & & $574(534)$ & $0.930 * * *$ & 0.255 \\
Total sales value (in \$) & 4050 & $3,381,389$ & $41,400,000$ & & 534 & $1,536,746$ & $8,015,190$ \\
Year of birth & 4180 & 1955 & 15.622 & & 574 & 1958 & 14.990 \\
\hline
\end{tabular}

The primary market sample consists of Western, contemporary artists only.

$* * *$ The difference in proportions of the auction participation rates between men and women is statistically significant on a $1 \%$ significance level.

All prices are in constant 2017 \$

Table 10 Auction

participation-artist-level regression results (primary market)

\begin{tabular}{ll}
\hline Variables & $\begin{array}{l}\text { Auction participation } \\
\text { Probit model }\end{array}$ \\
\hline Female & $-0.022^{* * *}$ \\
& $(0.006)$ \\
Year of birth & $-0.001^{* * *}$ \\
& $(0.000)$ \\
Artist nationality effects & Yes \\
Gallery effects & Yes \\
Observations & 4754 \\
\hline
\end{tabular}

Heteroscedasticity-consistent standard errors standard errors in parentheses.

$* * * p<0.01, * * p<0.05, * p<0.1$.

The probit model shows the marginal effects at the mean.

The primary market sample consists of Western, contemporary artists only

\section{Appendix}

See Fig. 5 and Table 11.

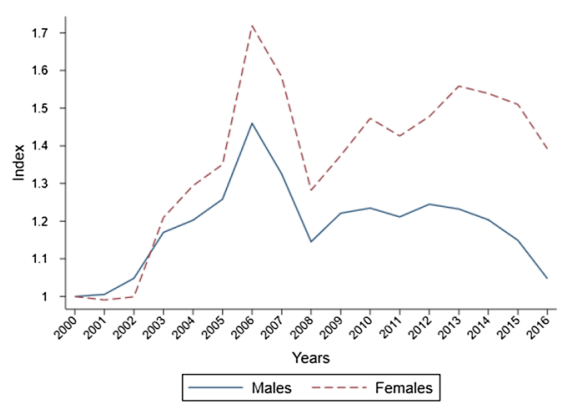

(a) Index for female and male artists - Full sample

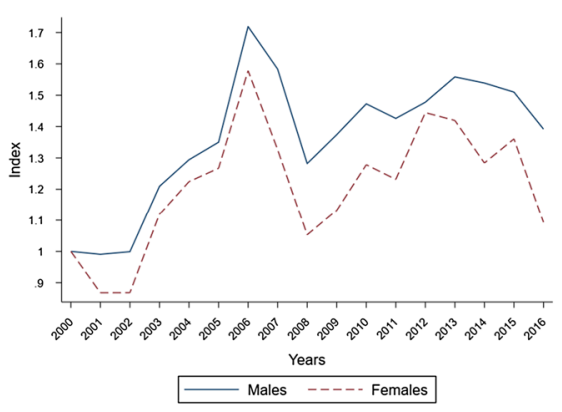

(b) Index for female and male artists - Contemporary sample

Fig. 5 Price index for female and male artists 


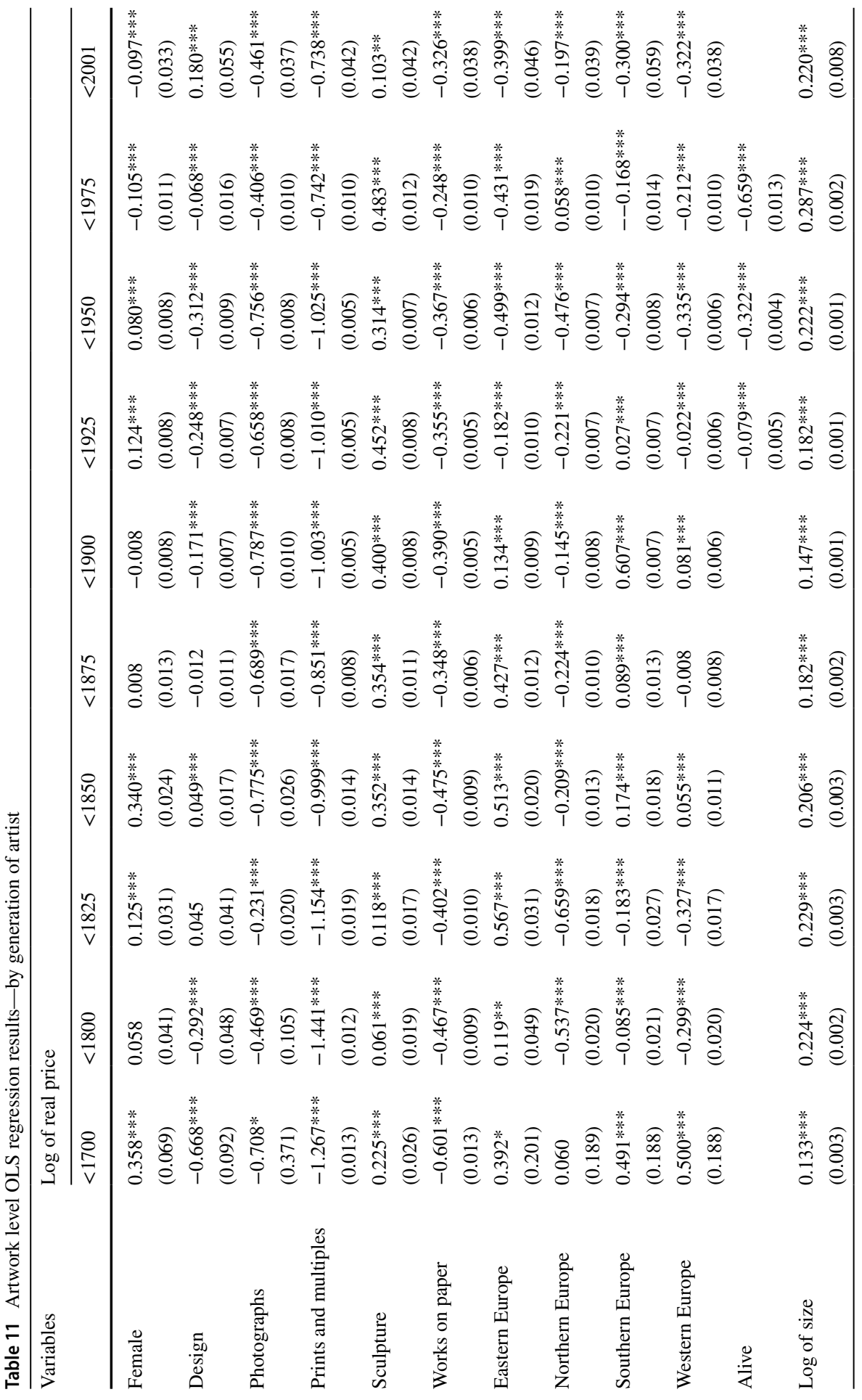




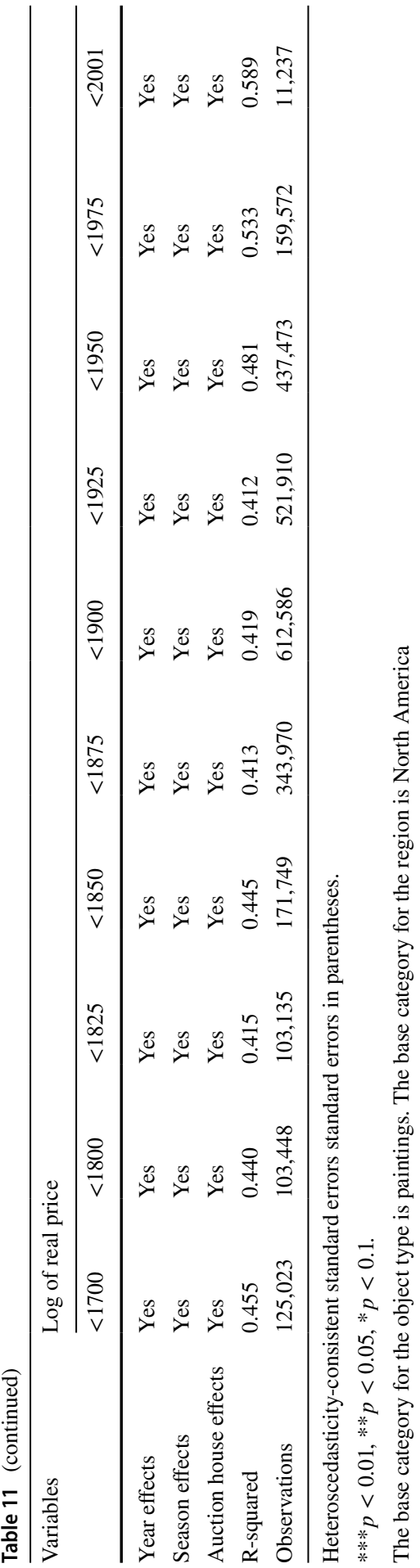


Open Access This article is licensed under a Creative Commons Attribution 4.0 International License, which permits use, sharing, adaptation, distribution and reproduction in any medium or format, as long as you give appropriate credit to the original author(s) and the source, provide a link to the Creative Commons licence, and indicate if changes were made. The images or other third party material in this article are included in the article's Creative Commons licence, unless indicated otherwise in a credit line to the material. If material is not included in the article's Creative Commons licence and your intended use is not permitted by statutory regulation or exceeds the permitted use, you will need to obtain permission directly from the copyright holder. To view a copy of this licence, visit http://creativecommons.org/licen ses/by/4.0/.

\section{References}

Adams, R. B., Kräussl, R., Navone, M. A., \& Verwijmeren, P. (2017). Is Gender in the Eye of the Beholder? Identifying Cultural Attitudes with Art Auction Prices. Available at SSRN,. https://ssrn.com/abstr act $=3083500$.

Ashenfelter, O., \& Graddy, K. (2002). Art auctions: A survey of empirical studies. Microeconomic Theory eJournal. https://doi.org/10.3386/W8997.

Cameron, L., Goetzmann, W. N., \& Nozari, M. (2017). Art and gender: market bias or selection bias? Journal of Cultural Economics, 43, 1-29.

McAndrew, C. (2018). The Art Market 2018. Art Basel and UBS Publication.

National Museum of Women in the Arts. (2017). Get the Facts. http://www.nmwa.org/advocate/get-facts.

Pownall, R.A.J. (2017). TEFAF Art Market Report 2017. The European Fine Art Foundation.

Publisher's Note Springer Nature remains neutral with regard to jurisdictional claims in published maps and institutional affiliations. 